\title{
SCREENING OF ACHILLEA SANTOLINA FOR ANTI-DIABETIC ACTIVITY AND ITS COMPARISON WITH CARALLUMA TUBERCULATA.
}

1. MBBS, M.Phil

Assistant Professor Pharmacology Khyber Medical College, Peshawar. 2. MBBS

Medical Officer

Health Department, Peshawar

3. Ph.D Scholar

Pharmacist

Hayatabad Medical Complex,

Peshawar.

4. MBBS, FCPS

Senior Registrar Medicine

Fauji Foundation Hospital,

Peshawar.

5. MBBS, FCPS Trainee Vitreo Retina Ophthalmology,

Hayatabad Medical Complex,

Peshawar.

6. PhD Scholar

Pharmacist

Khyber Medical College, Peshawa

Correspondence Address:

Waheed lqbal

Department of Pharmacology,

Khyber Medical College.

waheediqbal4200@gmail.com

Article received on:

23/08/2019

Accepted for publication:

$21 / 12 / 2019$
Muhammad Saleh Faisal ${ }^{1}$, Asad Inayat ${ }^{2}$, Muhammad $\mathrm{Nabi}^{3}$, Waqar Hayat ${ }^{4}$, Muhammad Sajid Khan ${ }^{5}$, Waheed Iqbal ${ }^{6}$

ABSTRACT... Objectives: The study was designed to investigate the hypoglycaemic effect of Achillea santolina and its comparison with Caralluma tuberculata. Study Design: Experimental study. Setting: Khyber Medical University, Peshawar. Period: July 2017 to February 2018. Material \& Methods: Crude extract and carbon tetrachloride $\left(\mathrm{CCl}_{4}\right)$ extract of Achillea santolina were prepared and administered to normal and alloxan treated diabetic rabbits. These extracts were given in capsule form as well as in cooking oil and their effects on blood glucose levels were observed at $0,2,4,6,8,12$ and 24 hours of administration. The results were compared with Caralluma tuberculata. Results: The crude extract $200 \mathrm{mg} / \mathrm{kg}$ body weight of Achillea santolina showed marked reduction in mean blood glucose level at 2, 4, 8 and 12 hours with significant $(p<0.001)$ difference when compared with Caralluma tuberculata. The metformin 500 $\mathrm{mg} / \mathrm{kg}$ body weight was also given to compare its effects with the plant crude extracts, which was more or less intermediate between the crude extracts of Achillea santolina and Caralluma tuberculata. The diabetic rabbits were treated with $100 \mathrm{mg} / \mathrm{kg}$ body weight $\mathrm{CCl}_{4}$ fraction of Achillea in capsule form. Blood glucose levels dropped markedly at 2 hours and further more at 4 hours as observed with Caralluma. Upon comparison with metformin, Achillea found to lower blood glucose levels but quite late than metformin. The diabetic rabbits were also treated with $100 \mathrm{mg} / \mathrm{kg}$ body weight $\mathrm{CCl}_{4}$ fraction of Achillea santolina in cooking oil and Caralluma was found to cause higher reduction in blood glucose levels than Achillea. Conclusion: Both Achillea santolina and Caralluma tuberculata lowered the blood glucose levels but the later turned out to be more significant in developing hypoglycaemia, particularly when taken with cooking oil.

Key words: $\quad$ Anti-diabetic, Achillea Santolina, Caralluma Tuberculata, Hypoglycaemic.

Article Citation: Faisal MS, Inayat A, Nabi M, Hayat W, Khan MS, Iqbal W. Screening of achillea santolina for anti-diabetic activity and its comparison with caralluma tuberculata. Professional Med J 2020; 27(7):1414-1419.

DOI: 10.29309/TPMJ/2020.27.07.4066

\section{INTRODUCTION}

Diabetes mellitus, which is basically a chronic disorder of metabolism with $5 \%$ incidence rate globally seems to be an epidemic now. According to survey, the number of diabetic patients has crossed 246 million worldwide and thus killing people more than AIDS. ${ }^{1}$ There any many factors which are responsible for this increase in prevalence specially in the last two decades i.e. sedentary life style, obesity, fast food, stress and other mental problems etc. There were around 382 million diabetic patients in the year 2013 and it is estimated that this figure is going to flare upto 592 million by $2035 .^{2}$ Currently, many treatment options are opted for management of diabetic patients, ranging from conventional therapy with exogenous insulin for Type 1 diabetes to oral antidiabetic drugs like sulphonylureas, biguanides etc for Type 2 diabetes. ${ }^{3}$ Inspite of availability of these conventional treatment modalities, there is an increased demand of natural products or Ayurveda with hypoglycaemic effects. ${ }^{4}$ In many Asian countries, since time immemorial, diabetic patients have been managed with various folk medicines and plant extracts. Active constituents of these plants are isolated by different techniques and then used as either lead compounds or directly as drugs. One of best examples is study on Galega officinalis, which leads to development of very well-known antidiabetic drug, metformin. Some of the plants used folklorically for same purpose includes $\mathrm{S}$. 
rebaudiana bertoni, Afzelia africana, Momordica charantia, Citrullus colocynthis, Allium sativum, Opuntia, Aloe and Artemisia. ${ }^{5,6}$ But very few of them got scientific scrutiny. Therefore, this study was an attempt to screen the hypoglycaemic effect of Achillea Santolina in normal and alloxan treated diabetic rabbits and its comparison with our published work on anti-diabetic effect of Caralluma Tuberculata. ${ }^{7}$

Caralluma tuberculata belongs to family Asclepiadaceae, a wild herb, grows in most of the hilly areas of Baluchistan and is used as a vegetable since centuries. Caralluma species have been used by humans as tonic, carminative, anti-helmintic and anti-tumor agent. ${ }^{8}$ It is reported to be effective in rheumatism and also known to have hypotensive effect. ${ }^{9,10}$

Achillea santolina also known as Achillea leptophylla is found in Khozdar, Quetta, Mastung and Kurram etc. They normally grows on inundated clay soils and also as an ornamental plant cultivated in gardens. It is used to relieve dryness of navel, stomach pain, common cold, skin lesions and its aqueous extract on mice have shown some anti-cancer activity. It is also used as treatment for diabetes mellitus in Baluchistan by traditional healers. ${ }^{11}$

\section{MATERIAL \& METHODS}

An experimental study was carried out at Khyber Medical University, Peshawar from July 2017 to February 2018.

Preparation of crude extracts of Achillea santolina The aerial parts of plant was washed and air dried. The dried material was grinded, passed through a mesh and put in distilled water at room temperature for several days, followed by squeezing in a muslin cloth. This procedure was repeated thrice.

Fractionation of Achillea santolina by carbon tetrachloride

Fractionation of Achillea was carried out by suspending its crude extract in water, partitioned with carbon tetrachloride $\left(\mathrm{CCl}_{4}\right)$ by vigorous shaking in a separating funnel. The $\mathrm{CCl}_{4}$ layer was separated and evaporated under reduced pressure on rotary evaporator. The resultant residue was then treated with methanol, the methanol soluble fraction was separated from the insoluble (water soluble) material and evaporated on rotary evaporator.

Healthy male rabbits weighing $1 \mathrm{~kg}$ to $1.5 \mathrm{~kg}$ of Oryctologus cunniculus species were selected. They were kept in animal house for one week under strict observation where they were fed upon clean water and fresh fodder.

To induce diabetes in normal rabbits, alloxan monohydrate was injected in a dose of $150 \mathrm{mg} /$ $\mathrm{kg}$ body weight using tuberculin syringe. A week later, blood levels of glucose were determined by glucose oxidase method and only those rabbits were included in the study whose blood glucose level lie in range $300-500 \mathrm{mg} / 100 \mathrm{ml} .{ }^{12,13}$

To study anti-diabetic activity, eighty rabbits were divided randomly into two main groups. Group I (Non-Diabetic Rabbits) and Group II (Diabetic) Rabbits.

\section{Group 1: Non-Diabetic Rabbits}

Each group was further divided into following sub-groups.

Subgroup $\mathbf{A}_{1}$ : Treated with crude extract of Caralluma tuberculata $200 \mathrm{mg} / \mathrm{kg}$ body weight.

Subgroup $\mathbf{B}_{1}$ : Treated with crude extract of Achillea santolina $200 \mathrm{mg} / \mathrm{kg}$ body weight.

Subgroup $C_{1}$ : Treated with Metformin 500 mg/kg body weight.

Subgroup $D_{1}$ : Serving as control receiving $20 \mathrm{ml}$ $2 \%$ gum tragacanth solution.

\section{Group II: Diabetic Rabbits}

Each group was further divided into following sub-groups.

Subgroup $\mathbf{A}_{2}$ : Treated with crude extract of Caralluma $200 \mathrm{mg} / \mathrm{kg}$ body weight (capsule form).

Subgroup $\mathbf{B}_{2}$ : Treated with crude extract of Achillea $200 \mathrm{mg} / \mathrm{kg}$ body weight (capsule form).

Subgroup $\mathbf{C}_{2}$ : Treated with Metformin 500 mg/kg body weight.

Subgroup $D_{2}$ : Serving as control receiving $20 \mathrm{ml}$ 
$2 \%$ gum tragacanth solution.

Subgroup $\mathrm{A}_{3}$ : Treated with $\mathrm{CCl}_{4}$ fraction of Caralluma $100 \mathrm{mg} / \mathrm{kg}$ body weight (capsule form).

Subgroup $\mathrm{B}_{3}$ : Treated with $\mathrm{CCl}_{4}$ fraction of Achillea $100 \mathrm{mg} / \mathrm{kg}$ body weight (capsule form).

Subgroup $\mathrm{C}_{3}$ : Treated with Metformin $500 \mathrm{mg} / \mathrm{kg}$ body weight.

Subgroup $D_{3}$ : Serving as control receiving $20 \mathrm{ml}$ $2 \%$ gum tragacanth solution.

Subgroup $\mathrm{A}_{4}$ : Treated with $\mathrm{CCl}_{4}$ fraction of Caralluma $100 \mathrm{mg} / \mathrm{kg}$ body weight (in cooking oil).

Subgroup $\mathrm{B}_{4}$ : Treated with $\mathrm{CCl}_{4}$ fraction of Achillea $100 \mathrm{mg} / \mathrm{kg}$ body weight (in cooking oil).

Subgroup $\mathrm{C}_{4}$ : Treated with Metformin $500 \mathrm{mg} / \mathrm{kg}$ body weight.

Subgroup $\mathrm{D}_{4}$ : Serving as control receiving $20 \mathrm{ml}$ soy bean cooking oil.

Data analysis was done using SPSS version 16 and expressed as Mean \pm SD. For calculation and comparison of the hypoglycemic effects at various doses \& different time intervals, ANOVA and Tukey's post hoc test were applied.

\section{RESULTS}

As shown in Table-I, treatment with Achillea reduced blood glucose level but Caralluma gives better results than Achillea in terms of hypoglycaemia. Also at 24 hours interval, this decrease is significantly low with Caralluma than Achillea $(p<0.05)$. The effect of Metformin on mean blood glucose level was intermediate between crude extract of Caralluma and Achillea. With metformin, blood glucose levels decreased after 2 and 4 hours interval but this started to increase from 8 to 24 hours. This increase is significantly higher compared to that at 12 hours interval $(p<0.01)$. Oral administration of $20 \mathrm{ml} \%$ gum tragacanth suspension did not produce any appreciable decrease in blood glucose levels.

Table-II shows that in capsule form, there was significantly low mean blood glucose levels after Achillea treatment as compared to Caralluma at 2 hours $(p<0.05)$ and 4 hours $(p<0.001)$. Compared to treatment with metformin, Caralluma and Achillea showed significantly low mean blood glucose level at 2 hours $(p<0.001)$, 4 hours $(p<0.001), 8$ hours $(p<0.001), 12$ hours $(p<0.001)$ and 24 hours interval $(p<0.001)$.

As clear from Table-III, Achillea reduced blood glucose levels efficiently till 12 hours but in comparison with Caralluma, the later decreased blood glucose levels more significantly at 2 hours $(p<0.001)$; 4 hours $(p<0.001)$; 8 hours $(p<0.001)$ and 12 hours $(p<0.001)$ but at 24 hours, the difference between these levels was not statistically significant $(p=0.2)$. Similarly, between Achillea and metformin, Achillea lowers the mean blood glucose levels quite late as compared to metformin.

\begin{tabular}{|c|c|c|c|c|}
\hline Time interval & \multicolumn{2}{|c|}{ Crude extract $\mathbf{2 0 0} \mathbf{~ m g} / \mathbf{k g}$ body weight } & $\mathbf{5 0 0} \mathbf{~ m g} / \mathbf{k g}$ body weight & $\mathbf{2 0 ~} \mathbf{~ I l}$ \\
\hline (Hours) & Caralluma Tuberculata & Achillea santolina & Metformin & $\mathbf{2 \%}$ Gum tragacanth \\
\hline 0 & $\mathrm{~A}_{1}$ & $\mathrm{~B}_{1}$ & $\mathrm{C}_{1}$ & $\mathrm{D}_{1}$ \\
\hline 2 & $104.33 \pm 1.33$ & $107.00 \pm 1.78$ & $92.16 \pm 0.83$ & $94.17 \pm 0.60$ \\
\hline 4 & $79.67 \pm 2.96$ & $97.17 \pm 2.32$ & $82.00 \pm 0.96$ & $94.00 \pm 0.58$ \\
\hline 8 & $73.17 \pm 2.64$ & $88.00 \pm 2.51$ & $72.50 \pm 1.31$ & $94.33 \pm 0.81$ \\
\hline 12 & $80.33 \pm 2.23$ & $83.50 \pm 1.08$ & $79.66 \pm 1.76$ & $93.50 \pm 0.67$ \\
\hline 24 & $72.50 \pm 0.88$ & $89.00 \pm 2.20$ & $87.16 \pm 0.75$ & $91.67 \pm 0.50$ \\
\hline
\end{tabular}

Table-l. Mean blood glucose levels in $\mathrm{mg} / \mathrm{dl}$ of non-diabetic rabbits after oral administration of crude extracts of Caralluma tuberculata, Achillea santolina, Metformin and $2 \%$ gum tragacanth 


\begin{tabular}{|c|c|c|c|c|}
\hline \multirow{2}{*}{$\begin{array}{c}\text { Time interval } \\
\text { (Hours) }\end{array}$} & \multicolumn{2}{|c|}{$\begin{array}{l}\text { Crude extract } 200 \mathrm{mg} / \mathrm{kg} \text { body weight } \\
\text { (Capsule form) }\end{array}$} & \multirow{2}{*}{$\begin{array}{c}500 \mathrm{mg} / \mathrm{kg} \text { body weight } \\
\text { Metformin }\end{array}$} & \multirow{2}{*}{$\begin{array}{c}20 \mathrm{ml} \\
2 \% \text { Gum tragacanth }\end{array}$} \\
\hline & Caralluma tuberculata & Achillea santolina & & \\
\hline & $\mathrm{A}_{2}$ & $\mathrm{~B}_{2}$ & $\mathrm{C}_{2}$ & $\mathrm{D}_{2}$ \\
\hline 0 & $318.16 \pm 2.05$ & $271.50 \pm 4.46$ & $335.16 \pm 3.04$ & $309.00 \pm 1.62$ \\
\hline 2 & $268.00 \pm 2.61$ & $246.00 \pm 5.40$ & $318.50 \pm 2.96$ & $309.66 \pm 1.78$ \\
\hline 4 & $263.00 \pm 1.24$ & $220.50 \pm 4.90$ & $306.50 \pm 1.65$ & $309.00 \pm 0.89$ \\
\hline 8 & $269.33 \pm 1.97$ & $233.17 \pm 4.45$ & $322.66 \pm 3.08$ & $309.16 \pm 3.25$ \\
\hline 12 & $260.33 \pm 1.50$ & $255.17 \pm 6.20$ & $327.00 \pm 2.50$ & $312.00 \pm 2.85$ \\
\hline 24 & $287.83 \pm 3.52$ & $271.50 \pm 4.72$ & $340.80 \pm 3.63$ & $310.33 \pm 2.50$ \\
\hline
\end{tabular}

\begin{tabular}{|c|c|c|c|c|}
\hline \multirow{2}{*}{$\begin{array}{c}\text { Time Interval } \\
\text { (Hours) }\end{array}$} & \multicolumn{2}{|c|}{$\begin{array}{l}\mathrm{CCl}_{4} \text { fraction } 100 \mathrm{mg} / \mathrm{kg} \text { body weight } \\
\text { (capsule form) }\end{array}$} & \multirow{2}{*}{$\begin{array}{c}500 \mathrm{mg} / \mathrm{kg} \text { body weight } \\
\text { Metformin }\end{array}$} & \multirow{2}{*}{$\begin{array}{c}20 \mathrm{ml} \\
2 \% \text { Gum Tragacanth }\end{array}$} \\
\hline & Caralluma Tuberculata & Achillea Santolina & & \\
\hline & $\mathrm{A}_{3}$ & $\mathrm{~B}_{3}$ & $\mathrm{C}_{3}$ & $\mathrm{D}_{3}$ \\
\hline 0 & $309.50 \pm 1.38$ & $326.00 \pm 2.60$ & $335.16 \pm 3.04$ & $309.00 \pm 1.62$ \\
\hline 2 & $194.16 \pm 2.49$ & $278.00 \pm 2.25$ & $318.50 \pm 2.96$ & $309.66 \pm 1.78$ \\
\hline 4 & $184.16 \pm 3.73$ & $265.00 \pm 2.04$ & $306.50 \pm 1.65$ & $309.00 \pm 0.89$ \\
\hline 8 & $207.67 \pm 3.68$ & $256.66 \pm 2.17$ & $322.66 \pm 3.08$ & $309.16 \pm 3.25$ \\
\hline 12 & $206.67 \pm 2.59$ & $253.33 \pm 1.92$ & $327.00 \pm 2.50$ & $312.00 \pm 2.85$ \\
\hline 24 & $257.33 \pm 3.66$ & $270.66 \pm 3.05$ & $340.80 \pm 3.63$ & $310.33 \pm 2.50$ \\
\hline
\end{tabular}

\begin{tabular}{|c|c|c|c|c|}
\hline \multirow{2}{*}{$\begin{array}{c}\text { Time interval } \\
\text { (Hours) }\end{array}$} & \multicolumn{2}{|c|}{$\begin{array}{l}\mathrm{CCl}_{4} \text { fraction } 100 \mathrm{mg} / \mathrm{kg} \text { body weight } \\
\text { (In cooking oil) }\end{array}$} & \multirow{2}{*}{$\begin{array}{c}500 \mathrm{mg} / \mathrm{kg} \text { body weight } \\
\text { Metformin }\end{array}$} & \multirow{2}{*}{$\begin{array}{c}20 \mathrm{ml} \\
\text { Soy Bean cooking oil }\end{array}$} \\
\hline & Caralluma tuberculata & Achillea santolina & & \\
\hline & $\mathrm{A}_{4}$ & $\mathrm{~B}_{4}$ & $\mathrm{C}_{4}$ & $\mathrm{D}_{4}$ \\
\hline 0 & $287.55 \pm 1.96$ & $336.50 \pm 2.12$ & $335.16 \pm 3.04$ & $301.00 \pm 2.08$ \\
\hline 2 & $142.33 \pm 1.74$ & $233.16 \pm 1.62$ & $318.50 \pm 2.96$ & $301.00 \pm 2.35$ \\
\hline 4 & $151.33 \pm 2.26$ & $226.16 \pm 1.62$ & $306.50 \pm 1.65$ & $302.66 \pm 3.48$ \\
\hline 8 & $153.16 \pm 3.13$ & $230.00 \pm 2.20$ & $322.66 \pm 3.08$ & $301.16 \pm 1.58$ \\
\hline 12 & $158.00 \pm 2.80$ & $242.33 \pm 2.23$ & $327.00 \pm 2.50$ & $303.16 \pm 2.24$ \\
\hline 24 & $164.66 \pm 3.23$ & $270.33 \pm 1.74$ & $340.80 \pm 3.63$ & $303.83 \pm 2.10$ \\
\hline
\end{tabular}

Table-IV. Blood glucose levels in $\mathrm{mg} / \mathrm{dl}$ of diabetic rabbits after oral administration of $\mathrm{CCl} 4$ fractions of Caralluma tuberculata (in cooking oil), Achillea santolina (in cooking oil), Metformin and $20 \mathrm{ml}$ Soybean cooking oil

Table-VI indicates that Achillea lowered blood glucose levels at 2 and 4 hours, but this reduction is more significant with Caralluma than Achillea. Significant rise in blood glucose levels with Achillea compared to Caralluma was observed at 12 hours interval $(p<0.001)$ and at 24 hours interval $(p<0.001)$.
In Table-III and 4, oral treatments with Achillea and Caralluma in capsule form and cooking oil, respectively were also analyzed to see which product produces more hypoglycaemic effect and it was observed that Caralluma tuberculata administered in cooking oil reduces blood glucose levels more efficiently. 


\section{DISCUSSION}

In the present study, two plants Achillea santolina and Caralluma tuberculata were taken into consideration. A series of experiments were carried out to assess the anti-diabetic activity of Achillea and its comparison was made with Caralluma to determine which plant lowers the blood glucose level more efficiently. To find out the active hypoglycaemic portion, different extracts were prepared using various solvents i.e. crude extract and carbon tetrachloride fractions $\left(\mathrm{CCl}_{4}\right)$ in both capsule form and in cooking oil.

Administration of Achillea crude extract in capsule form into diabetic rabbits produced just significant hypoglycaemia 2 hours after treatment that continued till 8 hours unlike Caralluma which caused highly significant reduction in blood glucose 2 hours after treatment which continued till 12 hours.

When carbon tetrachloride $\left(\mathrm{CCl}_{4}\right)$ fractions of Achillea and Caralluma in capsule form were compared, the best results in developing hypoglycaemia were obtained from Caralluma.

Carbon tetrachloride $\left(\mathrm{CCl}_{4}\right)$ fractions of Achillea and Caralluma in cooking oil were also administered into diabetic rabbits. Although both these plants developed significant hypoglycaemia 2 hours after treatment, but effect with Achillea last till 12 hours unlike Caralluma which continued upto 24 hours.

According to study done by pareek et al, a medicinal plant named $M$. emarginata lowers blood glucose level in diabetic rats at 100, 200 , and $400 \mathrm{mg} / \mathrm{kg}$, somewhat resembling to our findings. This hypoglycaemic action of $M$. emarginata could be due to increased insulin release either from the existing remnant $\beta$ cells or newly regenerated $\beta$ cells of pancreas. Similarly, many plants have been found to exhibit insulinogenic effect by stimulating pancreatic beta cells. ${ }^{14-16}$

It is claimed that different substances like anterior and posterior pituitary hormones, prostaglandins, corticosteroids and plants like Trigonella foenum produces hypoglycaemia by different means and mechanisms. Plants having alkaloids, terpenoids, glycosides and flavonoids exhibit antioxidant properties which is responsible for driving their hypoglycaemic actions, by regenerating the damaged beta pancreatic cells in addition to saponin induced inhibition of Na-Glucose co transporter-1 in intestine. ${ }^{17-20}$

Phytochemical screening of both Achillea and Caralluma confirmed the presence of flavonoids, alkaloids and saponin, suggesting similar modes of hypoglycaemic action. To determine the exact underlying mechanisms, a detailed phytochemical and pharmacological profiles of these plants are therefore necessary to establish.

\section{CONCLUSION}

Both Achillea santolina and Caralluma tuberculata lowers the blood glucose levels in mammalian model of rabbits but the later turned out to be more efficient in developing hypoglycaemia particularly when taken with cooking oil. However, the efficacy of herbal medications need to be further evaluated by well designed, controlled clinical studies.

\section{Copyright $\odot 21$ Dec, 2019.}

\section{REFERENCES}

1. Anonymous diabetes now a global threat gets own day. Sunday Times of India. 2006; 24:11.

2. Guariguata L, Whiting DR, Hambleton I, Beagley J, Linnenkamp U, Shaw JE. Global estimates of diabetes prevalence for 2013 and projections for 2035. Diabetes research and clinical practice. 2014; 103(2):137-49.

3. Pepato MT, Mori DM, Baviera AM, Harami JB, Vendramini RC, Brunetti IL. Fruit of the Jambolan tree (Eugenia jambolana Lam.) and experimental diabetes. J Ethnopharmacol. 2005; 96:43-8.

4. Venkatesh S, Reddy GD, Reddy BM, Ramesh M, Apparao AV. Antihyperglycemic activity of Carulluma attenuate. Fitoterapia. 2003; 74:274-9.

5. Gregersen S, Jeppesen PB, Holst JJ, Hermansen K. Antihyperglycemic effects of Stevioside in Type 2 diabetic subjects. Metab. 2004; 53:73-6. 
6. Akhtar MS, Ramzan A, Ali A, Ahmad M. Effect of Amla fruit (Emblica officinalis Gaertn.) on blood glucose and lipid profile of normal subjects and type 2 diabetic patients. International Journal of Food Sciences and Nutrition. 2011; 62(6):609-616.

7. Faisal MS, Hayat W, Inayat A, Sohaib M, Iqbal W. Comparison of caralluma tuberculata with metformin for anti-diabetic activity: An animal study. J Islamabad Med Dental Coll. 2019; 8(1):34-39.

8. Rehman, R.U., Chaudhary, M.F., Khawar, K.M. et al. In vitro propagation of Caralluma tuberculata and evaluation of antioxidant potential. Biologia. 2014; 69:341-345.

9. Poodineh J, Feizabad AK, Nakhaee A. Antioxidant activities of caralluma tuberculata on streptozotocin induced diabetic rats. Drug Development Research. 2015; 76(1):40-47.

10. Alamgeer, Ahmad T, Malik MNH, Mushtaq MN. et al. Evaluation of antihypertensive effect of aqueous methanol extract of caralluma tuberculata n.e.br in sprauge dawley rats. Tropical Journal of Pharmaceutical Research. 2015; 14(3): 455-462.

11. Rehman A and Zaman K. Medicinal plants with hypoglycaemic activity. J Ethnopharmacol. 2011; 26:1-5.

12. Liu T, Zhao H, Li J. Korantzopoulos P, Li J. Rosiglitazone attenuates atrial structural remodelling and atrial fibrillation promotion in alloxan-induced diabetic rabbits. Cardiovascular Therapeutics. 2014; 32(4): 178183.

13. Ahmad M, Kamran SH, Mobasher A. Protective effect of crude curcuma longa and its methanolic extract in alloxanized rabbits. Pak. J. Pharm. Sci. 2014; 27(1):121-128.
14. Pareek H, Sharma S, Khajja BS, Jain K, Jain GC. Evaluation of hypoglycemic and anti-hyperglycemic potential of Tridax procumbens (Linn.) BMC Complement Altern Med. 2009; 9:48.

15. Jiaa $Q$, Liub X, Wua X, Wanga $R$, Hua X, Lia $Y$, et al. Hypoglycemic activity of a polyphenolic oligomerrich extract of cinnamomum parthenoxyl bark in normal and streptozotocin induced diabetic rats. Phytomedicine. 2009; 16:744-750.

16. Gireesh G, Thomas SK, Joseph B, Paulose CS. Antihyperglycemic and insulin secretory activity of costus pictus leaf extract in streptozotocin induced diabetic rats and in in vitro pancreatic islet culture. $J$ Ethnopharmacol. 2009; 123:470-474.

17. Sharma RA, Singh B, Singh D. Ethnomedicinal, pharmacological properties and chemistry of some medicinal plants of Boraginaceae in India. Journal of Medicinal Plants Research. 2009; 3(13):1153-75

18. Swaroop A, Bagchi M, Kumar P. et al. Safety, efficacy and toxicological evaluation of a novel, patented anti-diabetic extract of Trigonella Foenum-Graecum seed extract. Toxicology Methods and Mechanisms. $2014 ; 24(7): 495-503$.

19. Hakkim FL, Girija S, Kumar RS, Jalaluddeen MD. Effect of aqueous and ethanol extracts of cassia auriculata L. flowers on diabetes using alloxan induced diabetic rats. Int J Diabetes Metab. 2007; 15:100-6.

20. Tiwari AK, Rao JM. Diabetes mellitus and multiple therapeutic approaches of phytochemicals: Present status and future prospects. Curr Sci. 2002; 83:30-8.

\begin{tabular}{|c|c|c|c|}
\hline \multicolumn{4}{|c|}{ AUTHORSHIP AND CONTRIBUTION DECLARATION } \\
\hline Sr. \# & Author(s) Full Name & Contribution to the paper & Author(s) Signature \\
\hline 1 & $\begin{array}{l}\text { Muhammad Saleh Faisal } \\
\text { Asad Inavat }\end{array}$ & $\begin{array}{l}\text { Planning, Data collection, } \\
\text { Manuscript writing. } \\
\text { Manuscript writing. Statistical. }\end{array}$ & \\
\hline 3 & Muhammad Nabi & Data collection. & \\
\hline 4 & Waqar Hayat & Manuscript writing. & \\
\hline 5 & Muhammad Sajid Khan & Critical analysis, Bibliography. & \\
\hline 5 & Waheed Iqbal & Data analysis. & \\
\hline
\end{tabular}

